\title{
Development and health status of Centropomus undecimalis parasitized by Rhabdosynochus rhabdosynochus (Monogenea) under different salinity and temperature conditions
}

\author{
Desenvolvimento e estado de saúde de Centropomus undecimalis parasitado por \\ Rhabdosynochus rhabdosynochus (Monogenea) sob diferentes condiçóes de salinidade e temperatura \\ Giovanni Lemos de Mello ${ }^{1,2 *}$; Gabriela Tomas Jerônimo ${ }^{3}$; Karen Roberta Tancredo ${ }^{3}$; Jéssica Brol ${ }^{1}$; \\ Evelyn Jacques de Almeida ${ }^{1}$; Maurício Laterça Martins ${ }^{3}$; Mônica Yumi Tsuzuki ${ }^{2}$

\begin{abstract}
${ }^{1}$ Laboratório de Aquicultura - LAQ, Departamento de Engenharia de Pesca, Universidade do Estado de Santa Catarina - UDESC, Laguna, SC, Brasil

${ }^{2}$ Laboratório de Peixes e Ornamentais Marinhos - LAPOM, Departamento de Aquicultura, Universidade Federal de Santa Catarina -UFSC, Florianópolis, SC, Brasil

${ }^{3}$ Laboratório de Sanidade de Organismos Aquáticos - AQUOS, Departamento de Aquicultura, Universidade Federal de Santa Catarina - UFSC, Florianópolis, SC, Brasil
\end{abstract}

Received June 12, 2015

Accepted July 21, 2015

\begin{abstract}
This study evaluated the correlation of hematological parameters with the mean abundance of the monogenean helminth Rhabdosynochus rhabdosynochus in Centropomus undecimalis reared at different temperatures and salinities. The experimental conditions were: $28^{\circ} \mathrm{C} / 0 \mathrm{ppt}$ (parts per thousand); $28^{\circ} \mathrm{C} / 15 \mathrm{ppt} ; 28^{\circ} \mathrm{C} / 32 \mathrm{ppt} ; 25^{\circ} \mathrm{C} / 0 \mathrm{ppt} ; 25^{\circ} \mathrm{C} / 15$ ppt; and $25^{\circ} \mathrm{C} / 32$ ppt. The prevalence was $100.0 \%$ in fish at $28{ }^{\circ} \mathrm{C} / 15 \mathrm{ppt}, 28{ }^{\circ} \mathrm{C} / 32 \mathrm{ppt}$ and $25^{\circ} \mathrm{C} / 15 \mathrm{ppt}$, which was significantly different $(\mathrm{p}<0.05)$ from those at $25^{\circ} \mathrm{C} / 32 \mathrm{ppt}$. The red blood cell $(\mathrm{RBC})$ count, hematocrit and total leukocyte (WBC) count were significantly higher in fish at $28{ }^{\circ} \mathrm{C} / 15 \mathrm{ppt}$ and $28{ }^{\circ} \mathrm{C} / 32 \mathrm{ppt}$. The mean abundance of $R$. rhabdosynochus, hematocrit and $\mathrm{RBC}$ showed positive correlations $(\mathrm{P}<0.05)$ with temperature $(\rho=0.3908 ; \rho=0.4771$ and $\rho=0.2812)$. Mean abundance showed negative correlations with hemoglobin $(\rho=-0.3567)$ and mean corpuscular hemoglobin concentration (MCHC) $(\rho=-0.2684)$. No correlation between abundance and salinity was detected among the experimental conditions $(\rho=-0.0204)$. The low numbers of monogeneans recorded ( $\mathrm{min}-1$ and max -33$)$ explain the few changes to fish health. This suggests that these experimental conditions may be recommended for development of rearing of $C$. undecimalis in Brazil, without any influence or economic losses from $R$. rhabdosynochus.
\end{abstract}

Keywords: Common snook, parasitology, water quality, hematology, Monogenea, Rhabdosynochus.

\section{Resumo}

Este estudo avaliou a correlação dos parâmetros hematológicos com a abundância média de helmintos monogenea Rhabdosynochus rhabdosynochus em robalo-flecha, Centropomus undecimalis, cultivado em diferentes temperaturas e salinidades. As condiçôes experimentais foram: $28^{\circ} \mathrm{C} / 0 \%$; $28^{\circ} \mathrm{C} / 15 \%$; $28^{\circ} \mathrm{C} / 32 \% 0 ; 25{ }^{\circ} \mathrm{C} / 0 \%$ \% $25^{\circ} \mathrm{C} / 15 \%$; $25^{\circ} \mathrm{C} / 32 \%$ o. A prevalência (P) foi de $100,0 \%$ nos peixes de $28{ }^{\circ} \mathrm{C} / 15 \%$ o, $28{ }^{\circ} \mathrm{C} / 32 \%$, $25^{\circ} \mathrm{C} / 15 \%$ o significativamente diferente $(\mathrm{p}<0,05)$ dos peixes de $25^{\circ} \mathrm{C} / 32 \%$ o $(\mathrm{P}=75,0 \%)$. O número de eritrócitos, hematócrito e leucócitos totais foram significativamente maiores nos peixes mantidos a $28^{\circ} \mathrm{C} / 15 \%$ e $28^{\circ} \mathrm{C} / 32 \%$. A abundância média de $R$. rhabdosynochus, hematócrito e número de eritrócitos mostraram correlação positiva $(\mathrm{p}<0,05)$ com a temperatura $(\rho=0,3908 ; \rho=0,4771$ e $\rho=0,2812$, respectivamente). Houve correlação negativa da abundância média com a hemoglobina $(\rho=-0,3567)$ e a concentração de hemoglobina corpuscular média (CHCM) $(\rho=-0,2684)$. Não houve correlação entre a abundância e a salinidade entre os tratamentos $(\rho=-0,0204)$. O baixo número de Monogenea registrado (mín: 1 e máx: 33) justifica as poucas alteraçóes na saúde dos animais avaliados. Isso sugere que essas condiçóes experimentais de cultivo podem ser recomendadas para um futuro desenvolvimento do cultivo de C. undecimalis no Brasil, sem que haja influência e perdas econômicas associadas a mortalidades, por parasitos $R$. rhabdosynochus.

Palavras-chave: Robalo, parasitologia, qualidade de água, hematologia, Monogenea, Rhabdosynochus.

*Corresponding author: Giovanni Lemos de Mello. Laboratório de

Aquicultura - LAQ, Departamento de Engenharia de Pesca, Universidade

do Estado de Santa Catarina - UDESC, Rua Cel Fernandes Martins, 270,

Progresso, CEP 88790-000, Laguna, SC, Brasil. e-mail: giovanni.mello@udesc.br 


\section{Introduction}

The common snook, Centropomus undecimalis (Bloch, 1792), is distributed in tropical and subtropical areas of the west coast of the Atlantic Ocean, from Cape Canaveral, Florida, USA, to southern Brazil (ALVAREZ-LAJONCHERE \& TSUZUKI, 2008). It is considered to be a diadromous, euryhaline, stenothermic and estuarine-dependent fish found in rivers, estuaries and coastal lagoons and along rocky shores (McMICHAEL et al., 1989; POPE et al., 2006). The common snook is considered to be the largest and also the fastest growing snook of all the species of the genus Centropomus in the Americas, and is a sporting fish of high market value (TUCKER, 2005). The species has received high priority with regard to conservation and aquaculture issues, due to its ecological and economic characteristics (WINNER et al., 2010).

With the intensification of fish farming, sanitary problems have become more frequent, making it necessary to periodically monitor fish health conditions. On this view, hematological investigations contribute to the evaluation of the organism's state of defense for facing the common challenges in aquaculture, in which fish are exposed to high stocking densities, parasites, changes to environmental quality and to the physical-chemical parameters of the water, and unbalanced diet (RANZANI-PAIVA et al., 2013).

Hematological parameters are recognized as secondary indicators of stress when increased red blood cell count, hematocrit, hemoglobin concentration and leukopenia are observed (WEDEMEYER et al., 1990; WOJTASZEK et al, 2002; PIERSON et al., 2004). For C. undecimalis, studies relating to hematology under fish-farming conditions are scarce. However, some laboratory studies have been conducted on the congeneric species C. parallelus (RANZANI-PAIVA et al., 2008; SANTOS et al., 2009, 2012; MARTINS et al., 2010; BARBOSA et al., 2011; SILVA et al., 2011). Recently, Dotta et al. (2015) evaluated the hematological parameters of the mutton snapper (Lutjanus analis) reared in cages, and observed significant increases in the hematocrit and total numbers of leukocytes and monocytes after 30 days of rearing, in comparison with fish in their natural environment.

In South America, knowledge of the parasitic fauna of farmed marine fish can still be considered to be at an initial stage despite the great ichthyological diversity and number of potential host species. Most research has been in relation to taxonomic aspects of helminth species, mainly developed in Brazil, Chile, Peru and Argentina (LUQUE, 2004).

Few studies have described and identified parasites in the common snook. Tavares \& Luque (2003) identified a new species of Acantholochus (Copepoda: Bomolochidae) in the coastal zone of the state of Rio de Janeiro, Brazil. The trematode Acanthocollaritrema umbilicatum Travassos, Freitas \& Bührnheim 1965 (Digenea: Acanthocollaritrematidae) was collected in the intestine of $C$. undecimalis reared in Itamaracá, Pernambuco (ROBALDO \& PADOVAN, 1998). The ecological community of metazoan parasites of the common snook in the coastal area of Rio de Janeiro was studied by Tavares \& Luque (2004), who found nine species of parasites in 79 fish analyzed. Fujimoto et al. (2009) evaluated the hematological parameters and parasitic fauna of $C$. undecimalis in the Bragantina region, state of Pará, Brazil, and reported a decrease in the RBC count, lymphopenia and neutrophilia in fish parasitized with Rhabdosynochus sp.
(Monogenea), Bucephalussp. (Digenea), Cucullanussp. (Nematoda) and Lernanthropidae (Crustacea). Several studies have shown the influence of salinity on the growth and survival of marine fish (DENDRINOS \& THORPE, 1985; McCORMICK et al., 1989; IMSLAND et al., 2001). Additionally, temperature has been found to have a significant effect on numerous physiological processes in fish (BRETT \& GROVES, 1979). It is considered to be one of the most important environmental parameters, given that it directly affects the metabolism, oxygen consumption, growth and survival of marine organisms (JIAN et al., 2003).

In this context, studies relating to sanitary aspects of the common snook are required in order to gain an understanding of the state of health of this fish under farmed conditions and in fluctuating environments. The aim of this study was to evaluate the relationship between hematological parameters and the mean abundance of gill parasites in the common snook reared at different temperatures and salinities in a recirculating aquaculture system.

\section{Materials and Methods}

\section{Fish and experimental design}

A total of 540 juveniles $(2.9 \pm 0.5 \mathrm{~g})$ of $C$. undecimalis were obtained from the Marine Aquaculture Laboratory (LAPMAR/UFSC) and were transferred to the Aquaculture Laboratory (LAQ), State University of Santa Catarina (UDESC), located in Laguna, Santa Catarina, Brazil, where the experiment was conducted.

The fish were maintained for 90 days with a combination of different temperatures $\left(25\right.$ and $\left.28^{\circ} \mathrm{C}\right)$ and salinities (0, 15, $32 \mathrm{ppt}$ ), divided into six treatments with three replicates each: $28^{\circ} \mathrm{C} / 0 \mathrm{ppt}$; $28{ }^{\circ} \mathrm{C} / 15$ ppt; $28{ }^{\circ} \mathrm{C} / 32 \mathrm{ppt} ; 25^{\circ} \mathrm{C} / 0$ ppt; $25^{\circ} \mathrm{C} / 15 \mathrm{ppt}$; and $25^{\circ} \mathrm{C} / 32 \mathrm{ppt}$. Each experimental unit was stocked with 30 juveniles $\left(150 \mathrm{fish} / \mathrm{m}^{3}\right)$.

Six recirculation systems (one for each combination of temperature and salinity) were used. Each system had three tanks of $200 \mathrm{~L}$ connected to a macroenvironment of $150 \mathrm{~L}$ capacity, provided with a biological and mechanical filter, activated carbon, heaters and an ultraviolet filter in the return pipe.

The fish were fed until they reached apparent satiation, twice a day, using a commercial feed for marine fish $(61.7 \%$ CP crude protein and $11.6 \% \mathrm{EE}$ - ethereal extract). The dissolved oxygen concentration, temperature, $\mathrm{pH}$ and salinity conditions were monitored daily using a $\mathrm{HANNA}^{\circledR}$ multiparameter device (HANNA ${ }^{\circledR}$ Instruments, USA; model HI 9828). N-NH 3 , N-NO, $\mathrm{N}-\mathrm{NO}_{3}$ and $\mathrm{PO}_{4}$ were measured every week using a colorimetric method (Alfakit ${ }^{\circledR}$, Brazil; model AT100P), and alkalinity was measured by means of an acid titration kit.

\section{Samples collection}

After experimental period, 12 fish per treatment (four fish per replicate) were collected for hematological and parasitological analyzes, totalizing 72 animals. All procedures were performed in accordance with the principles of the Ethics Committee for Animal Experimentation of the University of the State of Santa Catarina - CETEA / UDESC, protocol number 1.10.13. 


\section{Hematological analysis}

Blood was withdrawn from the caudal vein with syringes containing EDTA 5\% to evaluate the hematocrit percentage by microhematocrit method (RANZANI-PAIVA et al., 2013); hemoglobin concentration by the cianometahemoglobin (RANZANIPAIVA et al., 2013); total erythrocyte count (RBC) in a Neubauer chamber after dilution 1:200 in saline solution $0.9 \%$, mean corpuscular volume (MCV); and mean corpuscular hemoglobin concentration (MCHC) (RANZANI-PAIVA et al., 2013). The total number of leukocytes (WBC) and thrombocytes were obtained by indirect method from extensions stained with May-Grünwald-Giemsa-Wright (MGGW) (ISHIKAWA et al., 2008).

\section{Parasitological analysis}

Immediately after blood collection, fish were sacrificed by cerebral concussion (CONCEA, 2013) and the mucus from the body surface was collected by scraping with blade and observed by light microscopy for detection of parasites. The gills were collected according to Jerônimo et al. (2011), for parasites observation and quantifications. The quantified Monogenea specimens were mounted on blades with Hoyer's for easy viewing of sclerotized structures, important for identification at species level (bars, anchors and hooks - haptor), vagina and the male copulatory complex (penis and accessory piece). Some individuals were stained with Gomori trichrome to visualize the internal structures. After staining, they were clarified with Faia Creosote and mounted on permanent slides with Canada balsam (EIRAS et al., 2006). Prevalence rate, mean intensity and mean abundance were calculated according to Bush et al. (1997) and analyzed by the Quantitative Parasitology ${ }^{\circledR}$ 3.0 software (REICZIGEL \& RÓZSA, 2005).

\section{Statistical analysis}

The data were checked for normality of distribution and homoscedasticity by means of the Kolmogorov-Smirnov and Bartlett tests, respectively. The treatments were compared using factorial analysis of variance (ANOVA) and the means were compared using Tukey's test $(\mathrm{p}<0.05)$. The data were transformed $\left(\mathrm{Y}^{1 / 2}\right.$ arcsine $\left.\mathrm{Y}^{1 / 2}\right)$ as needed. The variables also were subjected to Pearson correlation analysis.

\section{Results}

The water quality parameters were maintained at acceptable levels for the species. There were no significant differences among the treatments with regard to dissolved oxygen concentration $\left(6.2 \pm 1.0 \mathrm{mg} \cdot \mathrm{L}^{-1}\right), \mathrm{pH}(7.8 \pm 0.2), \mathrm{N}-\mathrm{NH}_{3}\left(0.1 \pm 0.1 \mathrm{mg} \cdot \mathrm{L}^{-1}\right)$, $\mathrm{N}-\mathrm{NO}_{2}\left(0.1 \pm 0.1 \mathrm{mg} . \mathrm{L}^{-1}\right), \mathrm{N}-\mathrm{NO}_{3}\left(0.6 \pm 0.3 \mathrm{mg} . \mathrm{L}^{-1}\right)$ or $\mathrm{PO}$ $\left(1.3 \pm 0.5 \mathrm{mg} \cdot \mathrm{L}^{-1}\right)$. Significant differences were only observed in relation to the parameters that are directly affected by increased salinity, with higher values for higher salinities, such as alkalinity $(0$ ppt: $47.9 \pm 5.3 ; 15$ ppt: $66.0 \pm 9.2$; and 32 ppt: $\left.76.6 \pm 8.3 \mathrm{mg} \cdot \mathrm{L}^{-1} \mathrm{CaCO}_{3}\right)$. The parameters obtained during this study were $28.0 \pm 0.4{ }^{\circ} \mathrm{C}$ and $24.9 \pm 0.9^{\circ} \mathrm{C}$ for water temperature and $0.3 \pm 0.1 \mathrm{ppt}, 14.9 \pm 1.5 \mathrm{ppt}$ and $32.5 \pm 3.5 \mathrm{ppt}$ for salinity.

No parasites were found on the skin and fins but the monogenean Rhabdosynochus rhabdosynochus Mizelle and Blatz, 1941 (Dactylogyridae: Diplectanidae) was observed on the gills. The highest prevalence (100\%) was observed in fish at $28^{\circ} \mathrm{C} / 15 \mathrm{ppt}, 28^{\circ} \mathrm{C} / 32 \mathrm{ppt}$ and $25^{\circ} \mathrm{C} / 15 \mathrm{ppt}$, being significantly different $(\mathrm{p}<0.05)$ from the fish at $25^{\circ} \mathrm{C} / 32 \mathrm{ppt}(75 \%)$. The mean intensity of infection differed significantly among the experimental conditions, such that the lowest values were among the fish at $28{ }^{\circ} \mathrm{C} / 0 \mathrm{ppt}(9.2 \pm 10.2)$ and the highest were among those at $28^{\circ} \mathrm{C} / 15 \mathrm{ppt}(27.1 \pm 6.2)$. The mean abundance was lower $(\mathrm{p}<0.05)$ among fish at $28^{\circ} \mathrm{C} / 0$ ppt and $25^{\circ} \mathrm{C} / 32 \mathrm{ppt}(7.7 \pm 9.8$ and $8.2 \pm 7.3$, respectively $)$ (Table 1).

The average values for weight and length were greater from the fish maintained at higher temperature and did not differ with regard to salinity (Table 2). Significant difference on weight and length of examined fish could be associated with temperature and salinity conditions once no difference was observed among fish maintained in 28 and $25^{\circ} \mathrm{C}$. The hematological analysis showed that there were higher values for RBC, hematocrit and WBC in fish at $28{ }^{\circ} \mathrm{C} / 15 \mathrm{ppt}$ and $28^{\circ} \mathrm{C} / 32 \mathrm{ppt}$ than among those at $25^{\circ} \mathrm{C} / 15$ ppt (Table 2). Hemoglobin and MCHC were higher $(\mathrm{p}<0.05)$ in the fish at $25^{\circ} \mathrm{C} / 0 \mathrm{ppt}(11.4 \pm 2.0$ and $57.8 \pm 20.8$ respectively) than in the fish maintained at $28{ }^{\circ} \mathrm{C} / 15 \mathrm{ppt}$ and $28^{\circ} \mathrm{C} / 32$ ppt. Total thrombocytes were lower in the fish at T6 $(2.9 \pm 1.8)$, being significantly different from those at $28^{\circ} \mathrm{C} / 0 \mathrm{ppt}$ and $28^{\circ} \mathrm{C} / 15 \mathrm{ppt}(7.1 \pm 2.7$ and $6.3 \pm 3.1)$. No difference in MCV was found among the experimental conditions.

The mean abundances of $R$. rhabdosynochus, hematocrit and RBC showed positive correlations $(\mathrm{p}<0.05)$ with temperature ( $\rho=0.3908 ; \rho=0.4771$ and $\rho=0.2812$ respectively) (Table 3 ).

Table 1. Mean values ( \pm standard deviation) of prevalence (P), mean intensity (MI), mean abundance (MA), minimum and maximum number of parasites Rhabdosynochus rhabdosynochus (PN) in Centropomus undecimalis, cultured under different conditions of temperature and salinity.

\begin{tabular}{ccccc}
\hline Temperature/salinity & $\mathbf{P}(\%)$ & MI & MA & PN \\
\hline $28^{\circ} \mathrm{C} / 0 \mathrm{ppt}$ & $83.3^{\mathrm{ab}}$ & $9.2 \pm 10.2^{\mathrm{b}}$ & $7.7 \pm 9.8^{\mathrm{b}}$ & $1-33$ \\
$28^{\circ} \mathrm{C} / 15 \mathrm{ppt}$ & $100^{\mathrm{a}}$ & $27.1 \pm 6.2^{\mathrm{a}}$ & $27.1 \pm 6.2^{\mathrm{a}}$ & $11-30$ \\
$28^{\circ} \mathrm{C} / 32 \mathrm{ppt}$ & $100^{\mathrm{a}}$ & $16.8 \pm 6.5^{\mathrm{ab}}$ & $16.8 \pm 6.5^{\mathrm{b}}$ & $6-29$ \\
$25^{\circ} \mathrm{C} / 0 \mathrm{ppt}$ & $91.7^{\mathrm{a}}$ & $14.5 \pm 9.9^{\mathrm{ab}}$ & $13.3 \pm 10.4^{\mathrm{ab}}$ & $4-35$ \\
$25^{\circ} \mathrm{C} / 15 \mathrm{ppt}$ & $100^{\mathrm{a}}$ & $11.8 \pm 5.3^{\mathrm{b}}$ & $11.8 \pm 5.3^{\mathrm{b}}$ & $4-23$ \\
$25^{\circ} \mathrm{C} / 32 \mathrm{ppt}$ & $75^{\mathrm{b}}$ & $10.9 \pm 6.2^{\mathrm{b}}$ & $8.2 \pm 7.3^{\mathrm{b}}$ & $2-20$ \\
\hline
\end{tabular}

Means with the same letters are not significantly different. 
Table 2. Fish weight and length, and hematological parameters of Centropomus undecimalis cultured during 90 days under different conditions of water temperature $\left(25\right.$ and $\left.28^{\circ} \mathrm{C}\right)$ and salinity (0, 15 and $\left.32 \mathrm{ppt}\right)$. RBC: red blood cell; MCV: mean corpuscular volume; MCHC: mean corpuscular hemoglobin concentration; WBC: total leukocyte.

\begin{tabular}{|c|c|c|c|c|c|c|}
\hline \multirow[t]{2}{*}{ Variables } & \multicolumn{6}{|c|}{ Temperature/salinity } \\
\hline & $28^{\circ} \mathrm{C} / 0 \mathrm{ppt}$ & $28^{\circ} \mathrm{C} / 15 \mathrm{ppt}$ & $28^{\circ} \mathrm{C} / 32 \mathrm{ppt}$ & $25^{\circ} \mathrm{C} / 0 \mathrm{ppt}$ & $25^{\circ} \mathrm{C} / 15 \mathrm{ppt}$ & $25^{\circ} \mathrm{C} / 32 \mathrm{ppt}$ \\
\hline Weight (g) & $18.6 \pm 6.0^{\mathrm{a}}$ & $23.9 \pm 7.3^{a}$ & $18.6 \pm 6.2^{\mathrm{a}}$ & $13.1 \pm 4.3^{b}$ & $12.5 \pm 4.4^{\mathrm{b}}$ & $11.3 \pm 3.9^{\mathrm{b}}$ \\
\hline Total length $(\mathrm{cm})$ & $13.6 \pm 1.4^{\mathrm{a}}$ & $14.9 \pm 1.5^{\mathrm{a}}$ & $13.7 \pm 1.4^{\mathrm{a}}$ & $12.2 \pm 1.3^{b}$ & $12.1 \pm 1.5^{\mathrm{b}}$ & $11.6 \pm 1.3^{\mathrm{b}}$ \\
\hline $\operatorname{RBC}\left(x 10^{6} \cdot \mu \mathrm{L}^{-1}\right)$ & $2.7 \pm 0.5^{\mathrm{ab}}$ & $3.1 \pm 0.4^{\mathrm{a}}$ & $2.9 \pm 0.3^{\mathrm{a}}$ & $2.4 \pm 0.7^{\mathrm{ab}}$ & $2.4 \pm 0.3^{b}$ & $2.4 \pm 3.8^{b}$ \\
\hline Hematocrit (\%) & $22.6 \pm 4.4^{\mathrm{ab}}$ & $24.7 \pm 3.2^{\mathrm{a}}$ & $24.4 \pm 2.8^{\mathrm{a}}$ & $19.9 \pm 4.7^{\mathrm{ab}}$ & $19.3 \pm 3.4^{\mathrm{b}}$ & $22.1 \pm 4.3^{\mathrm{ab}}$ \\
\hline Hemoglobin (g. $\left.\mathrm{dL}^{-1}\right)$ & $10.1 \pm 1.1^{\mathrm{ab}}$ & $8.7 \pm 1.2^{\mathrm{b}}$ & $9.1 \pm 0.5^{b}$ & $11.4 \pm 2.0^{\mathrm{a}}$ & $9.8 \pm 1.9^{\mathrm{ab}}$ & $10.6 \pm 1.7^{\mathrm{ab}}$ \\
\hline MCV (fL) & $84.9 \pm 7.8$ & $79.9 \pm 8.3$ & $85.2 \pm 15.6$ & $83.3 \pm 12.6$ & $81.9 \pm 12.5$ & $92.7 \pm 13.9$ \\
\hline $\mathrm{MCHC}\left(\mathrm{g} \cdot \mathrm{dL}^{-1}\right)$ & $46.3 \pm 13.7^{\mathrm{ab}}$ & $35.2 \pm 6.2^{\mathrm{b}}$ & $37.9 \pm 5.0^{\mathrm{b}}$ & $57.8 \pm 20.8^{\mathrm{a}}$ & $41.0 \pm 30.4^{\mathrm{ab}}$ & $49.9 \pm 12.9^{\mathrm{ab}}$ \\
\hline WBC $\left(x 10^{3} \cdot \mu \mathrm{L}^{-1}\right)$ & $16.6 \pm 3.3^{\mathrm{ab}}$ & $18.0 \pm 3.4^{\mathrm{a}}$ & $17.7 \pm 3.3^{\mathrm{a}}$ & $12.9 \pm 3.4^{\mathrm{b}}$ & $16.8 \pm 2.8^{\mathrm{ab}}$ & $15.2 \pm 2.8^{\mathrm{ab}}$ \\
\hline Thrombocytes $\left(x 10^{3} \cdot \mu \mathrm{L}^{-1}\right)$ & $7.1 \pm 2.7^{\mathrm{a}}$ & $6.3 \pm 3.1^{\mathrm{a}}$ & $3.4 \pm 1.4^{\mathrm{ab}}$ & $4.8 \pm 1.9^{\mathrm{ab}}$ & $4.6 \pm 2.4^{\mathrm{ab}}$ & $2.9 \pm 1.8^{\mathrm{b}}$ \\
\hline Lymphocytes $\left(\mathrm{x} 10^{3} \cdot \mu \mathrm{L}^{-1}\right)$ & $15.8 \pm 3.3$ & $16.7 \pm 3.8$ & $17.1 \pm 3.2$ & $14.2 \pm 4.3$ & $15.9 \pm 2.8$ & $14.9 \pm 3.6$ \\
\hline Monocytes $\left(\mathrm{x} 10^{3} \cdot \mu \mathrm{L}^{-1}\right)$ & $0.0 \pm 0.0$ & $0.0 \pm 0.0$ & $0.0 \pm 0.0$ & $0.0 \pm 0.0$ & $0.0 \pm 0.0$ & $0.0 \pm 0.0$ \\
\hline Neutrophils $\left(\times 10^{3} \cdot \mu \mathrm{L}^{-1}\right)$ & $0.0 \pm 0.0$ & $0.0 \pm 0.0$ & $0.0 \pm 0.0$ & $0.0 \pm 0.0$ & $0.0 \pm 0.0$ & $0.0 \pm 0.0$ \\
\hline
\end{tabular}

Means with the same letters are not significantly different.

Table 3. Pearson correlation of hematological parameters under water temperature, salinity and mean abundance of Monogenea. Note: HTC: Hematocrit (\%); HMG: Hemoglobin (g.dL $\left.\mathrm{dL}^{-1}\right)$; RBC: Red Blood Cell (10 $\left.{ }^{6} \mathrm{LL}^{-1}\right)$; MCV: Mean Corpuscular Volume (fL); MCHC: Mean corpuscular hemoglobin concentration (g.dL $\left.{ }^{-1}\right)$; WBC: Total Leukocyte $\left(10^{3} \cdot \mu \mathrm{L}^{-1}\right)$; TRB: Thrombocytes $\left(10^{3} \cdot \mu \mathrm{L}^{-1}\right)$; $\mathrm{MA}$ : Mean abundance of monogenean.

\begin{tabular}{|c|c|c|c|c|c|c|c|c|c|c|c|c|c|}
\hline Parameters & Temperature & Salinity & HTC & HMG & RBC & MCV & MCHC & WBC & TRB & LIN & MON & NEU & MA \\
\hline Temperature & 1.0000 & $-0.0003^{\mathrm{NS}}$ & $0.3908^{*}$ & $-0.4439^{*}$ & $0.4771^{*}$ & $-0.0751^{*}$ & $-0.4460^{*}$ & $-0.1307^{\mathrm{NS}}$ & 0.0574 & $-0.0463^{\mathrm{NS}}$ & $-0.0422^{\mathrm{NS}}$ & $0.1319^{\mathrm{NS}}$ & $0.2812^{*}$ \\
\hline Salinity & & 1.0000 & $0.1651^{\mathrm{NS}}$ & -0.1565 & -0.0070 & $0.2185^{*}$ & $-0.1976^{\mathrm{NS}}$ & $0.1972^{\mathrm{NS}}$ & $-0.4368^{*}$ & $0.1139^{\mathrm{NS}}$ & $0.0961^{\mathrm{NS}}$ & $-0.2789^{\mathrm{NS}}$ & $-0.0204^{\mathrm{NS}}$ \\
\hline HTC & & & 1.0000 & $-0.4079^{*}$ & $0.6532^{*}$ & $0.4744^{*}$ & $-0.8414^{*}$ & $-0.0489^{\mathrm{NS}}$ & $-0.3445^{*}$ & $0.0815^{\mathrm{NS}}$ & $0.0274^{\mathrm{NS}}$ & $-0.1520^{\mathrm{NS}}$ & $0.1152^{\mathrm{NS}}$ \\
\hline HMG & & & & 1.0000 & $-0.3519^{*}$ & $-0.0793^{*}$ & $0.7815^{*}$ & $-0.1539^{\mathrm{NS}}$ & $0.3538^{*}$ & $0.1923^{\mathrm{NS}}$ & $-0.1510^{\mathrm{NS}}$ & $-0.1117^{\mathrm{NS}}$ & $-0.3567^{*}$ \\
\hline $\mathrm{RBC}$ & & & & & 1.0000 & $-0.3434^{*}$ & $-0.6211^{*}$ & $-0.1234^{\mathrm{NS}}$ & $-0.3098^{*}$ & $0.0723^{\mathrm{NS}}$ & $-0.1223^{\mathrm{NS}}$ & $0.0282^{\mathrm{NS}}$ & $0.2110^{\mathrm{NS}}$ \\
\hline $\mathrm{MCV}$ & & & & & & 1.0000 & $-0.3247^{*}$ & $0.1011^{\mathrm{NS}}$ & $-0.0813^{\mathrm{NS}}$ & $0.0062^{\mathrm{NS}}$ & $0.2078^{\mathrm{NS}}$ & $-0.2368^{\mathrm{NS}}$ & $-0.0945^{\mathrm{NS}}$ \\
\hline $\mathrm{MCHC}$ & & & & & & & 1.0000 & $-0.0964^{\mathrm{NS}}$ & $0.4441^{*}$ & $0.0445^{\mathrm{NS}}$ & $-0.1078^{\mathrm{NS}}$ & $0.0550^{\mathrm{NS}}$ & $-0.2684^{*}$ \\
\hline WBC & & & & & & & & 1.0000 & $-0.1773^{\mathrm{NS}}$ & $0.1933^{\mathrm{NS}}$ & $-0.0261^{\mathrm{NS}}$ & $-0.2231^{\mathrm{NS}}$ & $-0.0765^{\mathrm{NS}}$ \\
\hline TRB & & & & & & & & & 1.0000 & $-0.0072^{\mathrm{NS}}$ & $0.0270^{\mathrm{NS}}$ & $-0.0028^{\mathrm{NS}}$ & $-0.0765^{\mathrm{NS}}$ \\
\hline LIN & & & & & & & & & & 1.0000 & $-0.7079^{*}$ & $-0.6614^{*}$ & $-0.0590^{\mathrm{NS}}$ \\
\hline $\mathrm{MON}$ & & & & & & & & & & & 1.0000 & $-0.0560^{\mathrm{NS}}$ & $-0.1393^{\mathrm{NS}}$ \\
\hline NEU & & & & & & & & & & & & 1.0000 & $0.2405^{\mathrm{NS}}$ \\
\hline MA & & & & & & & & & & & & & 1.0000 \\
\hline
\end{tabular}

${ }^{*}=$ significant correlation $(\mathrm{p}<0.05) .{ }^{\mathrm{NS}}=$ no significant correlation $(\mathrm{p} \geq 0.05)$.

Mean abundance showed negative correlations with hemoglobin $(\rho=-0.3567)$ and MCHC $(\rho=-0.2684)$. There was no correlation between abundance and salinity among the experimental conditions $(\rho=-0.0204)$.

\section{Discussion}

Monogenean parasites are mostly found parasitizing both wild and cultivated fish and are considered to be important pathogenic agents in aquaculture (TURGUT, 2012). They feed on the epithelial cells from the body surface and gills, or blood in some cases (EIRAS, 1994). The genus Rhabdosynochus was originally described by Mizelle \& Blatz (1941) in C. undecimalis in East Florida, USA. In the present study, we recorded $R$. rhabdosynochus in the gills of common snook, but other species can be found in Brazil, such as
R. hargisi, R. hudsoni and Rhabdosynochus sp. in common snook from Itamaracá, Pernambuco (KRITSKY et al., 2001). Abdallah et al. (2012) described $R$. guanduensis on the gills of common snook examined in Guandu river, state of Rio de Janeiro. Kritsky et al. (2010) proposed a redescription of the genus based on the fish specimens examined from Centropomidae fish in Florida, USA, and Mendoza-Franco et al. (2008) described $R$. alterinstitus, $R$. lituparvus, $R$. volucris and $R$. siliquaus parasitizing the gills of Centropomus nigrescens and Centropomus robalito, collected on the coast of Mexico.

Several factors influence monogenean egg eclosion and depend on the parasite species. Turbulence, photoperiod, temperature and mucus released by the host can stimulate eclosion and determine the success of parasitism (EIRAS, 1994).

Temperature is considered to be one of the most important factors in determining parasite abundance (OZTURK \& 
ALTUNEL, 2006). The fish examined in this study showed a positive correlation between monogenean abundance and temperature. Fish maintained at $28{ }^{\circ} \mathrm{C}$ were more parasitized than those kept at $25^{\circ} \mathrm{C}$, independently of the salinity.

In fact, several studies have focused on the correlation between temperature and parasite abundance and/or egg eclosion (GANNICOTT \& TINSLEY, 1998). These authors observed greater viability of eggs of Discocotyle sagittata in rainbow trout (Oncorhynchus mykiss) kept at $13-18^{\circ} \mathrm{C}$. Similarly, Özer \& Erdem (1999) reported higher prevalence of Dactylogyrus anchoratus in Cyprinus carpio in summer $\left(25.5-26.2^{\circ} \mathrm{C}\right)$ than in winter $\left(13.6-12.7^{\circ} \mathrm{C}\right)$. Our results are also supported by the findings of Barker \& Cone (2000), who reported that prevalence and abundance had a positive correlation with water temperature $\left(10-24^{\circ} \mathrm{C}\right)$.

In this study, salinity did not influence parasite abundance, and this may have been related to the fact that the common snook is considered to be a euryhaline and diadromous species (McMICHAEL et al., 1989; POPE et al., 2006). These fish can be found inhabiting environments of variable salinities (McMICHAEL et al., 1989) and consequently the parasite species may have developed the same resistance over the years due to coevolution.

In the study by Violante-González et al. (2010), parasite richness in $C$. nigrescens was evaluated at five different sites in a coastal lagoon located in Guerrero, Mexico. At sites where salinity was $15 \mathrm{ppt}$, the authors recorded greater diversity of the monogeneans $R$. alterinstitus and Cornutohaptor nigrescensi than at sites with salinity of 6 ppt.

Few studies on fish hematology in relation to sanitary issues have been conducted in Brazil, especially in relation to $C$. undecimalis. Fujimoto et al. (2009) reported that this metazoan parasite was found in common snook from Bragança, Pará, in northeastern Brazil. Nevertheless, other studies have focused on C. parallelus (RANZANI-PAIVA et al., 2008; SANTOS et al., 2009, 2012; MARTINS et al., 2010; BARBOSA et al., 2011; SILVA et al., 2011). The variations in the hematological parameters in freshwater and marine fishes may be related to length, gender or maturation (RANZANI-PAIVA \& SOUZA, 2004).

In analyzing the hematological parameters, the fish kept at a lower temperature $\left(25^{\circ} \mathrm{C}\right)$ showed decreased $\mathrm{RBC}$ counts and hematocrit levels without positive correlation with the abundance of $R$. rhabdosynochus. In contrast, Fujimoto et al. (2009) observed decreased values for RBC and hematocrit in parasitized common snook.

The relationships between hematocrit and RBC, and between hemoglobin and hematocrit, are known as hematimetric indices. These are used to classify anemia, which is an unpaired condition of the blood relating to transporting oxygen to tissues (RANZANI-PAIVA et al., 2013). In this study, these parameters did not show any correlation with parasite abundance, except for hemoglobin, which that showed a negative correlation.

Hematological alterations can be related to the eutrophication level of the environment, as observed by Seriani et al. (2013) in common snook examined in Cananéia and São Vicente, state of São Paulo. Fish from São Vicente, which was the most eutrophicated region, showed the highest values for hematocrit, mean corpuscular volume, WBC and RBC.

In the present study, fish were maintained under good conditions in the recirculation system under controlled water quality. The low numbers of parasites observed (1 to 33) may have been strongly related to the experimental cultivation conditions. It can be inferred that a recirculation system is recommended for commercial maintenance of common snook, avoiding economic losses caused by monogeneans, since the water quality is monitored.

\section{Acknowledgements}

The authors thank Drs Luís André Nassr de Sampaio (FURG), Ronaldo Olivera Cavalli (UFRPE), Luís Alejandro Vinatea Arana (UFSC), Hilton Amaral Júnior (EPAGRI) and Alex Pires de Oliveira Nuñer (UFSC) for critical review of the manuscript, and CNPq for grant to M.L. Martins.

\section{References}

Abdallah VD, Azevedo RK, Luque JLF. Three new species of Monogenea (Platyhelminthes) parasites of fish in the Guandu river, southeastern Brazil. Acta Sci Biol Sci 2012; 34(4): 483-490. http://dx.doi.org/10.4025/ actascibiolsci.v34i4.10466

Alvarez-Lajonchère L, Tsuzuki MY. A review of methods for Centropomus spp. (snooks) aquaculture and recommendations for the establishment of their culture in Latin America. Aquacult Res 2008; 39(7): 684-700. http://dx.doi.org/10.1111/j.1365-2109.2008.01921.x.

Barbosa MC, Jatobá A, Vieira FN, Silva BC, Mouriño JLP, Andreatta ER, et al. Cultivation of juvenile fat snook (Centropomus parallelus Poey, 1860) fed probiotic in Laboratory conditions. Braz Arch Biol Technol 2011; 54(4): 795-801. http://dx.doi.org/10.1590/S1516-89132011000400020.

Barker DE, Cone DK. Occurrence of Ergasilus celestis (Copepoda) and Pseudodactylogryrus anguillae (Monogenea) among wild eels (Anguilla rostrata) in relation to stream flow, $\mathrm{pH}$ and temperature and recommendations for controlling their transmission among captive eels. Aquaculture 2000; 187(3-4): 261-274. http://dx.doi.org/10.1016/S0044-8486(00)00324-0

Brett JR, Groves TDD. Physiological energetics. In: Hoar WS, Randall DJ, Brett JR. Fish Physiology. New York: Academic Press; 1979. p. 279-352.

Bush AO, Lafferty KD, Lotz JM, Shostak AW. Parasitology meets ecology on its own terms: Margolis et al. revisited. J Parasitol 1997; 83(4): $575-$ 583. http://dx.doi.org/10.2307/3284227. PMid:9267395.

Conselho Nacional de Controle de Experimentação Animal - CONCEA. Diretrizes da prática de eutanásia do CONCEA [online]. Brasília: CONCEA; 2013 [cited 2014 Jun 13]. Available from: http://www.mct.gov.br/ upd_blob/0226/226746.pdf.

Dendrinos P, Thorpe JP. Effects of reduced salinity on growth and body composition in the European bass Dicentrarchus labrax (L.). Aquaculture 1985; 49(3-4): 333-358. http://dx.doi.org/10.1016/0044-8486(85)90090-0.

Dotta G, Roumbedakis K, Sanches EG, Jerônimo GT, Cerqueira VR, Martins ML. Hematological profile of the red snapper Lutjanus analis captured in Florianópolis, SC, Brazil, and cultured in floating net cages. Bol Inst Pesca 2015; 41(1): 183-189.

Eiras J. Elementos de Ictioparasitologia. Porto: Fundação Eng. Antônio de Almeida; 1994. 
Eiras JC, Takemoto RM, Pavanelli GC. Métodos de estudo e técnicas laboratoriais em parasitologia de peixes. Maringá: Eduem; 2006.

Fujimoto RY, Santana CA, Carvalho WLC, Diniz DG, Barros ZMN, Varella JEA, et al. Haematology and metazoan parasites of camurim (Centropomus undecimalis, Bloch, 1792) captured in Bragança, PA, Brazil. Bol Inst Pesca 2009; 35(3): 441-450.

Gannicott AM, Tinsley RC. Environmental effects on transmission of Discocotyle sagittata (Monogenea): egg production and development. Parasitology 1998; 117(Pt 5): 499-504. http://dx.doi.org/10.1017/ S0031182098003205. PMid:9836315.

Imsland AK, Foss A, Gunnarsson S, Berntssen MHG, FitzGerald R, Bonga SW, et al. The interaction of temperature and salinity on growth and food conversion in juvenile turbo (Scophthalmus maximus). Aquaculture 2001; 198(3-4): 353-367. http://dx.doi.org/10.1016/S0044-8486(01)00507-5.

Ishikawa NM, Ranzani-Paiva MJT, Lombardi JV. Total leukocyte counts methods in fish, Oreochromis niloticus. Arch Vet Sci 2008; 13(1): 54-63.

Jerônimo GT, Martins ML, Ishikawa MM, Ventura AS, Tavares-Dias M. Métodos para coleta de parasitos. Macapá: EMBRAPA; 2011. Circular técnica.

Jian C-Y, Cheng SY, Chen JC. Temperature and salinity tolerances of yellowfin sea bream, Acanthopagrus latus, at different salinity and temperatures levels. Aquacult Res 2003; 34(2): 175-185. http://dx.doi. org/10.1046/j.1365-2109.2003.00800.x.

Kritsky DC, Boeger WA, Robaldo RB. Neotropical Monogenoidea. 38. Revision of Rhabdosynochus Mizelle and Blatz, 1941 (Polyonchoinea: Dactylogyridea: Diplectanidae), with descriptions of two new species from Brazil. Comp Parasitol 2001; 68(1): 66-75.

Kritsky DC, Bakenhaster MD, Fajer-Avila EJ, Bullard SA. Rhabdosynochus spp. (Monogenoidea: Diplectanidae) infecting the gill lamellae of snooks, Centropomus spp. (Perciformes: Centropomidae), in Florida, and redescription of the type species, $R$. rhabdosynochus. J Parasitol 2010; 96(5): 879-886. http://dx.doi.org/10.1645/GE-2529.1. PMid:20496964.

Luque JL. Parasitologia de peixes marinhos na América do Sul. In: Ranzani-Paiva MJT, Takemoto RM, Lizama MAP. Sanidade de organismos aquáticos. São Paulo: Livraria Varela; 2004. p. 199-216.

Martins L, Paz AV, Brentano DM. Avaliação da geração de micronúcleo em juvenis de Centropomus parallelus (robalo-peva) expostos a diferentes concentrações salinas. RTC 2010; 2: 13-16.

McCormick SD, Saunders RL, MacIntyre AD. The effect of salinity and ration level on growth rate and conversion efficiency of Atlantic salmon (Salmo salar) smolts. Aquaculture 1989; 82(1-4): 173-180. http://dx.doi. org/10.1016/0044-8486(89)90406-7.

McMichael RJ Jr, Peters DM, Parsons GR. Early life history of the snook, Centropomus undecimalis, in Tampa Bay, Florida. Northeast Gulf Science 1989; 10(2): 113-125.

Mendoza-Franco EF, Violante-González J, Vidal-Martínez VM. New species of Rhabdosynochus Mizelle and Blatz 1941 (Monogenoidea: Diplectanidae) from the gills of centropomid fishes (Teleostei) off the Pacific Coast of Mexico. J Parasitol 2008; 94(1): 28-35. http://dx.doi. org/10.1645/GE-1241.1. PMid:18372618.

Mizelle JD, Blatz V. Studies on monogenetic trematodes. VI. Two new Dactylogyrid genera from Florida fishes. The Am Midland Nat J 1941; 26(1): 105-109. http://dx.doi.org/10.2307/2420758.

Özer A, Erdem O. The relationship between occurrence of ectoparasites, temperature and culture conditions: a comparison of farmed and wild common carp (Cyprinus carpio L., 1758) in the Sinop region of northern Turkey. J Nat Hist 1999; 33(4): 483-491. http://dx.doi. org/10.1080/002229399300209.

Ozturk MO, Altunel FN. Occurrence of Dactylogyrus infection linked to seasonal changes and host fish size on four cyprinid fishes in lake Manyas, Turkey. Acta Zool Hung 2006; 52(4): 407-415.

Pierson PM, Lamers A, Flik G, Mayer-Gostan N. The stress axis, stanniocalcin, and ion balance in rainbow trout. Gen Comp Endocrinol 2004; 137(3): 263-271. http://dx.doi.org/10.1016/j.ygcen.2004.03.010. PMid:15201064.

Pope KL, Blankinship DR, Fisher M, Patiño R. Status of the common snook (Centropomus undecimalis) in Texas. Tex J Sci 2006; 58(4): 325-332.

Ranzani-Paiva MJT, Souza ATS. Hematologia de peixes brasileiros. In: Ranzani-Paiva MJT, Takemoto RM, Lizama MAP. Sanidade de organismos aquáticos. São Paulo: Livraria Varela; 2004. p. 89-120.

Ranzani-Paiva MJT, Santos AA, Dias DC, Seriani R, Egami MI. Hematological and phagocytic response of the fat snook, Centropomus parallelus, reared in net cages, before and after inoculation with Saccharomyces cerevisiae. Bioikos 2008; 22(1): 29-35.

Ranzani-Paiva MJT, Pádua SB, Tavares-Dias M, Egami MI. Métodos para análise hematológica em peixes. Maringá: Eduem; 2013.

Reiczigel J, Rózsa L. Quantitative parasitology 3.0 [online]. 2005 [cited 2014 June 13]. Available from: http://www.zoologia.hu/qp/qp.html.

Robaldo RB, Padovan IP. Acanthocollaritrema umbilicatum Travassos, Freitas \& Bührnheim, 1965 (Digenea: Acanthocollaritrematidae) from the common snook, Centropomus undecimalis, from Itamaracá, state of Pernambuco, Brazil. Mem Inst Oswaldo Cruz 1998; 93(3): 303-307. PMid:9698863.

Santos AA, Egami MI, Ranzani-Paiva MJT, Juliano Y. Hematological parameters and phagocytic activity in fat snook (Centropomus parallelus): seasonal variation, sex and gonadal maturation. Aquaculture 2009; 296(34): 359-366. http://dx.doi.org/10.1016/j.aquaculture.2009.08.023.

Santos AA, Ranzani-Paiva MJT, da Veiga ML, Faustino L, Egami MI. Hematological parameters and phagocytic activity in fat snook (Centropomus parallelus) bred in captivity. Fish Shellfish Immunol 2012; 33(4): 953-961. http://dx.doi.org/10.1016/j.fsi.2012.08.005. PMid:22926256.

Seriani R, Abessa DMS, Pereira CDS, Kirschbaum AA, Assunção A, Ranzani-Paiva MJT. Influence of seasonality and pollution on the hematological parameters of the estuarine fish Centropomus parallelus. Braz J Oceanogr 2013; 61(2): 105-111. http://dx.doi.org/10.1590/ S1679-87592013000200003.

Silva WF, Egami MI, Santos AA, Antoniazzi MM, Silva M, Gutierre $\mathrm{RC}$, et al. Cytochemical, immunocytochemical and ultrastructural observations on leukocytes and thrombocytes of fat snook (Centropomus parallelus). Fish Shellfish Immunol 2011; 31(4): 571-577. http://dx.doi. org/10.1016/j.fsi.2011.07.019. PMid:21802518.

Tavares LER, Luque JL. A new species of Acantholochus (Copepoda: Bomolochidae) parasitic on Centropomus undecimalis (Osteichthyes: Centropomidae) from the coastal zone of the State of Rio de Janeiro, Brazil. Mem Inst Oswaldo Cruz 2003; 98(2): 241-245. http://dx.doi. org/10.1590/S0074-02762003000200013. PMid:12764441.

Tavares LER, Luque JL. Community ecology of metazoan parasites of the later juvenile common snook Centropomus undecimalis (Osteichthyes: Centropomidae) from the coastal zone of the State of Rio de Janeiro, Brazil. Braz J Biol 2004; 64(3A): 523-529. http://dx.doi.org/10.1590/ S1519-69842004000300015. PMid:15622849. 
Tucker JW Jr. Snook culture. Am Fish Soc Symp 2005; 46: 297-305.

Turgut E. Influence of temperature and parasite intensity on egg production and hatching of the monogenean Dactylogyrus extensus. Isr J Aquacult 2012; 64: 729-733.

Violante-González J, Mendoza-Franco EF, Rojas-Herrera A, Gil Guerrero S. Factors determining parasite community richness and species composition in black snook Centropomus nigrescens (Centropomidae) from coastal lagoons in Guerrero, Mexico. Parasitol Res 2010; 107(1): 59-66. http:// dx.doi.org/10.1007/s00436-010-1834-x. PMid:20336316.

Winner BL, Blewett DA, McMichael RH Jr, Guenther CB. Relative abundance and distribution of common snook along shoreline habitats of Florida estuaries. Trans Am Fish Soc 2010; 139(1): 62-79. http:// dx.doi.org/10.1577/T08-215.1.

Wedemeyer GA, Barton BA, McLeay DJ. Stress and acclimation. In: Schreck CB, Moyle PB. Methods for fish biology. Bethesda: American Fisheries Society; 1990. p. 491-527.

Wojtaszek J, Dziewulska-Szwajkowska D, Lozińska-Gabska M, Adamowicz A, Dzugaj A. Hematological effects of high dose of cortisol on the carp (Cyprinus carpio L.): cortisol effect on the carp blood. Gen Comp Endocrinol 2002; 125(2): 176-183. http://dx.doi.org/10.1006/ gcen.2001.7725. PMid:11884063. 